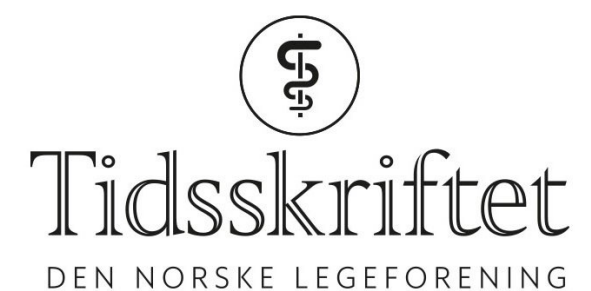

DEN NORSKE LEGEFORENING

\title{
Kosthold, mettet fett og epigenetikk
}

DEBATT

\section{TOR-ERIK WIDERØE}

E-post: tor-erik.wideroe@ntnu.no

Tor-Erik Widerøe (f. 1940) er professor emeritus ved Institutt for kreftforskning og molekylær medisin, Norges teknisk-naturvitenskapelige universitet.

Forfatter har fylt ut ICMJE-skjemaet og oppgir ingen interessekonflikter.

I en ny studie der man undersøkte sammenhenger mellom kosthold og dødelighet i en rekke land over hele verden, fant man at de som spiste mest fett og proteiner, levde lengst. Sammenhengen forstyrres av store miljøforskjeller. Kan epigenetikken forklare resultatene?

I en ny, prospektiv kohortstudie publisert i The Lancet var målet å finne sammenheng mellom inntak av makronæringsstoffer, totaldødelighet og kardiovaskulær sykdom og død (1). Studien inkluderte 135334 personer fra 18 land - tre høyinntektsland (Canada, Sverige og De forente arabiske emirater), 11 mellominntektsland (Argentina, Brasil, Chile, Kina, Colombia, Iran, Malaysia, okkupert palestinsk territorium, Polen, Sør-Afrika og Tyrkia) og fire lavinntektsland (Bangladesh, India, Pakistan og Zimbabwe).

Etter én innledende kostregistrering og en observasjonstid på 7,4 år ble landene gruppert etter hvor mye karbohydrater, mettet, umettet og flerumettet fett og protein innbyggerne konsumerte.

Spesielt i høyinntektsland var det et høyt inntak av alle typer fett og protein, et lavt inntak av karbohydrater og lav totalmortalitet. I middelinntekts- og lavinntektsland var det et høyt inntak av karbohydrater, et lavt inntak av fett og protein og høy totalmortalitet. Merkelig nok ble det ikke funnet forskjeller i kardiovaskulær sykdom og død.

Hyppigste bidrag til totalmortaliteten var kreftsykdommer, infeksjonssykdommer og lungesykdommer - typiske miljø-og livsstilsutløste sykdommer (2). Likevel ble det anbefalt at de globale retningslinjene for inntak av umettet og mettet fett burde liberaliseres - det vil si en ufarliggjøring av spesielt mettet fett.

\section{Ulike populasjoner}

Men er det mulig å finne en sann sammenheng mellom inntak av makronæringsstoffer, sykdom og død når levevilkårene er så forskjellige? Er miljøet en konfunderende faktor? Studiepopulasjonen besto av både moderne velferdsstater og områder preget av ekstrem fattigdom og krigsherjinger - altså en svært heterogen populasjon.

Epidemiologer kryssberegner hundrevis av mat- og livsstilsvariabler mot dødsrate for ulike lidelser, noe som resulterer i et stort antall sammenhenger. Noen av de positive sammenhengene vil være falske. Det er vanskelig, kanskje umulig, å gjennomføre 
troverdige studier på effektene av ulikt inntak av makronæringsstoffer i en studiepopulasjon med et bredt spekter av livsstilsfaktorer, fra velfungerende demokratier til land med ekstrem fattigdom og en befolkning preget av fysiske og psykiske traumer og manglende tilgang på helsetjenester.

Sykdom og tidlig død kan være relatert til ulik tilgang til fødevarer, medisinsk behandling og screening for kroniske sykdommer og forskjellig eksponering for smittsomme sykdommer og andre livsstilspåvirkninger.

\section{Var epigenetikk forklaringen?}

Innen epigenetisk epidemiologisk forskning søker man primært å identifisere genetiske og miljømessige risikofaktorer for sykdom (3). Epigenetikk er miljøutløste arvelige forandringer i genuttrykk uten endringer i den underliggende DNA-sekvensen.

Med epigenetikk menes en matrise av genspesifikke kjemiske reaksjoner som metylering og acetylering av histonproteiner på forskjellige steder i DNA-et og i mikroRNA-et (4). Det har vært påvist nær sammenheng mellom disse epigenetiske forandringene og en rekke sykdommer, som kreft, hjerte- og karsykdommer, lungesykdommer og nevrodegenerative sykdommer $(5,6)$.

Spesielt prenatale forhold som mors livsstil og psyke og ekstrem hunger påvirker barnet. Det kan føre til økt sykelighet og kortere levetid gjennom flere generasjoner $(7,8)$. Omsorgssvikt i tidlige barneår (9) og 20 år kortere levetid ved psykisk sykdom (10) har vært omtalt i Tidsskriftet. Posttraumatisk krigsstress kan føre til epigenetiske forandringer og dermed arvelige sykdommer og kortere levetid (11).

Epigenetikken gir en biologisk forklaring på det vi allerede vet, og den bygger bro mellom genetiske og miljømessige faktorer (6). Poenget er at ekstrem fattigdom, konflikter, krig og manglende stabilitet er faktorer som kan være av større betydning for sykelighet og tidlig død enn forskjeller i makroernæring.

\section{Feil konklusjon?}

Resultatene i PURE-studien forstyrres av store forskjeller i miljø og livsstil som globalt sett kan påvirke sykdom og levetid mer enn forskjeller i næringsstoffinntaket. Positive sammenhenger kan derfor være falske.

Epigenetisk forskning har gitt epidemiologene et biologisk verktøy til å finne miljøutløste årsaker og forklaring på sykdomsfordelingen i populasjoner, noe som kan være veiledende for forebyggende tiltak.

\footnotetext{
LITTERATUR:

1. Dehghan M, Mente A, Zhang X et al. Associations of fats and carbohydrate intake with cardiovascular disease and mortality in 18 countries from five continents (PURE): a prospective cohort study. Lancet 2017; 390: 2050 - 62. [PubMed][CrossRef]

2. Piñeros M, Znaor A, Mery L et al. A Global Cancer Surveillance Framework Within

Noncommunicable Disease Surveillance: Making the Case for Population-Based Cancer Registries. Epidemiol Rev 2017;39: 161 - 9. [PubMed]

3. Ladd-Acosta C, Fallin MD. The role of epigenetics in genetic and environmental epidemiology. Epigenomics 2016; 8: 271 - 83. [PubMed][CrossRef]

4. Champagne FA, Curley JP. Epigenetic mechanisms mediating the long-term effects of maternal care on development. Neurosci Biobehav Rev 2009; 33: 593 - 6oo. [PubMed][CrossRef]

5. Alegría-Torres JA, Baccarelli A, Bollati V. Epigenetics and lifestyle. Epigenomics 2011; 3: 267- 77 .

[PubMed][CrossRef]

6. Bakulski KM, Fallin MD. Epigenetic epidemiology: promises for public health research. Environ Mol
} 
Mutagen 2014; 55: 171 - 83. [PubMed][CrossRef]

7. Johnson SB, Riley AW, Granger DA et al. The science of early life toxic stress for pediatric practice and advocacy. Pediatrics 2013; 131:319 - 27. [PubMed][CrossRef]

8. Black RE, Victora CG, Walker SP et al. Maternal and child undernutrition and overweight in lowincome and middle-income countries. Lancet 2013; 382: 427-51. [PubMed][CrossRef]

9. Lien L, Huus G, Morken G. Psykisk syke lever kortere. Tidsskr Nor Legeforen 2015; 135: 246 - 8.

[PubMed][CrossRef]

10. Brandtzæg Næss A, Kirkengen AL. Er en belastet barndom knyttet til kortere telomerer? Tidsskr Nor Legeforen 2015; 135: 1356 - 6o. [PubMed][CrossRef]

11. Brubaker CR, Milner J. The epigenetics of Post-Traumatic Stress Disorder in women and PTSD in women veterans: implications for health policy. DNP Forum 2015; 1, nr. 1, art 7.

Publisert: 5. februar 2018. Tidsskr Nor Legeforen. DOI: 10.4045/tidsskr.18.0013 Mottatt 2.1.2018, første revisjon innsendt 15.1.2018, godkjent 15.1.2018.

(C) Tidsskrift for Den norske legeforening 2020. Lastet ned fra tidsskriftet.no 